\title{
Flow of Capital in the Mediterranean: Financial Connections between Genoa and Hospitaller Malta in the Seventeenth and Eighteenth Centuries
}

\section{Ivan Grech}

The availability of capital was a common problem for European and Mediterranean states in the early modern period. The inadequacy of taxation revenues, the escalating costs of military engagement, the upgrading of war machinery and the need to strengthen defences meant that rulers became more inclined to turn to banks and wealthy merchants to obtain more rapid flows of currency. ${ }^{1}$

While the powerful states on the mainland battled in the wake of the Protestant Reformation, Hospitaller Malta, on the Muslim-Christian frontier, was engaged in the "lesser war" against corsairing. Faced with the Barbary threat from North Africa, and forever wary of the Ottomans, the Order of St. John had to grapple with the financial burdens of plying the surrounding waters, fortifying its defences and, probably most daunting, providing for a growing population. Although it never engaged directly in a full-scale conflict after the siege of 1565, Hospitaller Malta constantly faced shortages. The corso and income from property on the continent seldom met the needs of the Treasury, forcing the Order to search for alternatives to bolster its finances.

Founded in Syria in the eleventh century, the original role of the Order of St. John was to assist pilgrims bound for the Holy Land. Using bequests, donations and direct purchases, the Hospital acquired property throughout Europe. These were grouped into estates (commanderies); the commanderies in a given territory comprised the priories, which were combined according to the eight languages that comprised the Order. Income from produce, leases and legacies provided the Hospital with most of its income. The funds the priories were obliged to send to the convent (Hospitaller headquarters) were

${ }^{1}$ For an overview of the costs of war in early modern Europe, see P. Kennedy, The Rise and Fall of the Great Powers (London, 1989), chapters 2 and 3.

International Journal of Maritime History, XVII, No. 2 (December 2005), 193-210. 
ories were obliged to send to the convent (Hospitaller headquarters) were called responsions. ${ }^{2}$

The Order's transition to a permanent military role took place in the twelfth century. It was dictated by the pressing military needs of the Frankish settlements in Syria, a frontier territory where confrontation with Islam was inescapable. By the time of its settlement in Malta in 1530, the Hospital had accumulated centuries of experience in warfare and was fully incorporated into Christianity's effort against the Ottoman Turks. Its participation in concerted maritime expeditions against Islamic fleets and outposts was periodically solicited by the Christian forces. ${ }^{3}$

Apart from sustaining this military initiative, the Order was burdened with the defence of its new post. ${ }^{4}$ Victory in 1565 spared the island from Muslim occupation and endowed the Order with glory, but it left Hospitaller Malta scarred psychologically. The fear of another Ottoman onslaught tormented the Order and conditioned the life of the convent until the later part of its stay on the island. This siege phobia, a legacy which pre-dated 1565 and reached back to the Knights' background on Rhodes, stayed with the Order and was periodically nurtured by rumours of Turkish preparations for war: a warning from a foreign envoy; a piece of hearsay delivered by an occasional merchant on his return from the Levant; a reference by a spy in the Porte; a report by the commander of a Christian ship stopping to replenish supplies; or a snippet accidentally overheard by an agent in a foreign court. ${ }^{5}$ Although such news often proved unfounded, nothing could be disregarded without investigation, which often was time consuming. But if confirmed, these rumours caused the Order

${ }^{2}$ C.H. Lawrence, Medieval Monasticism: Forms of Religious Life in Western Europe in the Middle Ages (London, 1989), 211-213; H.J.A. Sire, The Knights of Malta (London, 1994), 3-10; and A. Hoppen, "The Finances of the Order of St. John of Jerusalem in the Sixteenth and Seventeenth Centuries," Europe Studies Review, III, No. 2 (1973), 106 and 109-110. Income came from the spoglio - eighty percent of a Hospitaller's property which passed to the Order after death; the mortuary - the fruits of a commandery from the date of a commander's death until the start of the next financial year (1 May); and the vacancy - the fruits of the commandery accumulated in the following year. More income came from the passages, sums paid by newly-admitted Hospitallers. In 1533 the Order fixed a new, permanent rate for the responsions.

${ }^{3}$ Lawrence, Medieval Monasticism, 212-213; and B. Dal Pozzo, Historia della S. Religione Militare di S. Giovanni Gerosolimitano detta di Malta (2 vols., Verona, 1703-1715).

${ }^{4}$ In 1530 Charles $\mathrm{V}$ also entrusted the Order with the defence of Tripoli in Barbary, which was lost in 1551. Sire, Knights, 63 and 66.

${ }^{5}$ After withstanding the siege of 1480 , the Hospitallers lost Rhodes to the Ottomans in the siege of 1522. Ibid., 51-59. 
to introduce some short-term measures, such as summoning more Hospitallers, stocking the arsenals and grain stores or seeking support from foreign allies. The long-term measures generally involved improving the fortifications. This threat placed continuous pressure on the Order's coffers.

Tracing the state of the Order's Treasury at any time in its history is arduous. An in-depth study of its overall financial management in Malta has yet to be undertaken. Since records were not kept systematically, such an analysis could provide only a partial, and sometimes distorted, picture of the Order's finances. Accounts listing annual income and expenditures were not drawn up regularly, and the existing statements must be used with caution. Entries in the income columns, for example, at times included accounts receivable. Occasional accusations and manifestations of dissent by members of the island's intelligentsia further complicate matters. In 1670, for instance, a member of the clerical community wrote a memoriale accusing the Hospitaller hierarchy of oppressing Malta's church and people with taxes while refusing to disclose (or use) its considerable reserves. Moreover, it was only in the late seventeenth century that detailed records of expenditures were kept, and only in the second half of the eighteenth century did the Treasury start to publish year-end balance sheets from its receivers, the financial agents posted in the various priories to channel the responsions to the Treasury in Malta. ${ }^{6}$

It is difficult to argue, however, that while in Malta the Order was constantly under financial strain. ${ }^{7}$ Nonethless, indications of such conditions appear periodically. In 1767 , for example, the Council (the Order's governing body) deliberated about appropriate measures to curb the debt. The balance sheet for the financial year ending in April 1771 recorded a loss exceeding 80,000 scudi. And in 1775 , Treasury officials reported on what they described as the "huge debts" of the Common Treasury. ${ }^{8}$ But since such information is only sporadic, it is insufficient to sustain the argument that the Order constantly encountered financial difficulties and constantly needed capital. Where one can find tangible proof of these problems is in the choice of language used by successive magistracies. Indeed, the dispatches from Malta were replete with complaints about the dire straits of its coffers and the need for fresh

${ }^{6}$ Hoppen, "Finances," 103-105; M.A. Sant, "Coinage Problems Facing the Order of St. John in Malta" (Unpublished MA thesis, University of Malta, 1967), 193198; and Archives of the Order, Valletta (AOM) 634, 146-148.

${ }^{7}$ The exceptionality of the Order's financial crisis of the 1790 s warrants special attention and will be dealt with separately below.

${ }^{8}$ AOM 634, 12 December 1766, 209-210; and AOM 638, 495. 
funds. ${ }^{9}$ The frequency of these complaints, and the fact that more often than not they were addressed to the Order's agents and ministers abroad, should suppress the temptation to dismiss them as ploys to stimulate the generosity of foreign princes. It has been claimed, however, that the balance sheets might have been tampered with when the Hospital intended to beg for more in European courts. Fernand Braudel, for example, warns against accepting income accounts at face-value when discussing Don Juan's report on the possessions of Tunis after he captured it in $1573 .{ }^{10}$ To meet the need for funds, the Order had to adopt a two-fold approach. The first was to draw on its own resources. The second was to find alternative sources of revenue. In the implementation of both measures, Genoa played a significant role.

The collection of money from its European estates was a recurrent headache for the Order. The problem was often at the source, where receivers frequently found it difficult to gather the funds. The estates were at the mercy of their administrators, the elements and the socio-political situation in the territory in question. When and if the funds were collected, the task of transferring them to the Treasury in Malta presented other problems. The responsions collected from the various priories on the continent were usually transferred to Malta by well-established routes using a combination of cash and some form of credit, mainly bills of exchange and the bolla, the receipt issued by the Treasury which enabled agents to withdraw Hospitaller funds in Europe. The responsions drawn from the various priories in Iberia and France, which were a considerable portion of the Treasury's income, were usually transferred via Genoa directly to Malta or to Sicily for exchange purposes. Genoa, in fact, was a vital conduit through which remittances from Western Europe were channelled to Malta. The city offered some obvious advantages for the transfer of capital, including geographic location. ${ }^{11}$

${ }^{9}$ Some examples may be found in AOM 1421, ff. 228v-229r, Lascaris Castellar to the receivers of Palermo, Naples, Rome, Florence, Lombardy, Venice, Bohemia and Germany, 10 October 1643; AOM 1424, f. 134v, Castellar to the receivers of Palermo, Naples and Florence, and the procurators of Messina and Genoa, 10 August 1646; AOM 1445, f. 289, Cotoner to Ambassador Correa (Rome), 22 December 1676; AOM 1460, f. 30, Wignacourt to Ambassador Sacchetti (Rome), 18 March 1695; AOM 1507, Pinto to Grimaldi, 13 October 1749; and AOM 1515, ff. 48v-49r, Pinto to Grimaldi (Genoa), 27 February 1761. Dal Pozzo, Historia della S. Religione Militare, also refers to similar financial shortages.

${ }^{10}$ Hoppen, "Finances," 104; and F. Braudel, The Mediterranean and the Mediterranean World in the Age of Philip II (2 vols., London, 1972), I, 475.

${ }^{11}$ See for example, I. Grech, "Gli Orsini e l'alienazione dei beni della commenda di San Giovanni di Prè," in J. Costa Restagno (ed.), Riviera di Levante tra 
In early modern times, Genoa was still a popular port of call for vessels sailing in the western Mediterranean, despite the challenge of Leghorn which in the sixteenth century efficiently exploited its free port policy to divert traffic to its harbour. Ships coasting east along the Spanish and French shores would call at Genoa for provisions and refitting before resuming their trip southward to the central Mediterranean. Indeed, the Barcelona-Genoa route gained even greater prominence after the Battle of Lepanto, which led to Italy being flooded with huge quantities of Spanish capital..$^{12}$

It was normal practice for the Order to exploit scheduled trips along this maritime route for the transfer of funds. Its own galleys, those of the Spanish crown or even those of Genoa were called upon or chartered to ship funds to Sicily or Malta. The sums from the estates of one country or territory were grouped and then transferred to ports where they would be loaded onto these galleys. Spanish funds, for example, were usually transferred from ports such as Cartagena, Alicante or Barcelona, while French funds were collected at Marseilles. In February 1653, Grand Master Lascaris Castellar enthusiastically commented on the arrival from Marseilles of a fabulous sum, "the like of which has not been seen in the Convent for a long time." 13

The services of Genoese galleys were often used both for the transfer of these funds to Genoa and for their shipment to Malta or Sicily. When the monies were deposited in Genoa and needed to be transferred to Sicily, the Order at times sought the services of the city's silk galleys bound for Messina which, together with Catania, were the centres of the Sicilian silk industry. Certain logistical criteria had to be met. The transfers to Genoa or Sicily had to be coordinated with the voyages of the galleys, which mainly occurred in the mild seasons. This was especially important when the Order's galleys were involved in some stage of the operation. In 1605 two galleys of the Order's squadron on a mission around the Mediterranean called at Genoa to load Hospitaller funds. But in 1606 an attempt to use Hospitaller galleys to transfer Spanish funds to Genoa fell through, since by the time the proposal reached Malta the galleys had already passed Barcelona on their way to Marseilles. In 1613 a sum of Spanish doppie deposited in Genoa was to be shipped to Malta with the Hospitaller squadron on its return from Spain. In the summer of 1655 the squadron, returning from an expedition to the Levant, had to wait in

Emilia e Toscana. Un crocevia per l'Ordine di San Giovanni. Atti del Convegno Genova-Chiavari-Rapallo, 9-12 settembre 1999 (Genoa, 2001), 159.

${ }^{12} \mathrm{~T}$. Kirk, "Genoa and Livorno: Sixteenth and Seventeenth-Century Commercial Rivalry as a Stimulus to Policy Development," History, LXXXVI (2001), 3-17; and Braudel, Mediterranean, I, 487.

${ }^{13}$ Dal Pozzo, Historia della S. Religione Militare, II, 228-229; and AOM 1431, f. 58, Castellar to Spinola (Genoa), 28 February 1653. 
Messina for four days for the monies being shipped in Genoese galleys on their routine trip to load silk. In June 1722 the galleys, then at the service of the Viceroy of Sicily, were to leave for Civitavecchia soon after their assignment was over to collect and transport to Malta a sum from the Order's ambassador to Rome. Cash was not always carried on the large galleys. In 1634 a Maltese galiot called in Ragusa (Dubrovnik) with funds for the Hospitaller coffers in Venice. Modest sums did not require large vessels for their transport. In 1756 Grimaldi, the Hospitaller agent in Genoa, had only to wait for a Maltese brigantino or speronara returning from Spain to ship 1500 Spanish pieces-of-eight to Malta. ${ }^{14}$

Sending galleys solely to transfer funds was a luxury the Order could ill afford, and it was undertaken only in times of acute need. For example, in August 1655 the entire squadron of seven galleys was to be fitted in the shortest time possible to be sent to collect 200,000 scudi from France and Spain; the urgency was such that the fleet was given strict orders to ignore Barbary corsairs sighted in the Maltese channel. In 1708, two galleys were sent urgently to Genoa to collect 100,000 genovine. $^{15}$

Genoa also served as a deposit and redistribution point for the inflow of Hospitaller remittances from central Europe and northern Italy. Its position as the principal Mediterranean outlet for Milan was exploited by the Order more than once for the export of weapons, ammunition and armour from the foundries of the Lombard city. The same Milan-Genoa route was used for the remittance of funds: it was not unusual for funds from the estates in Germany and Lombardy to be collected in Milan for transfer to Genoa. In January 1605, the Order expressed its disappointment that only the modest sum of $2735 \mathrm{scudi}$ from Milan was deposited in Genoa. Pagliaro, the Hospitaller agent in Genoa, was reassured that the flow of funds from Milan would be greater in the near future. In 1606, 3600 scudi from Milan were deposited in Genoa for transfer to Messina. At the beginning of 1607,2000 scudi were to be transferred from

${ }^{14} \mathrm{AOM} 1384$, f. 229, Wignacourt to Pagliaro (Genoa), 29 July 1605; ff. $274 \mathrm{v}-275 \mathrm{r}$, Wignacourt to Pagliaro, 25 August 1605; and f. 129v, Wignacourt to Pagliaro (Genoa), 9 June 1606; T. Kirk, "The Implications of Ceremony at Sea: Some Examples from the Republic of Genoa (16th and 17th Centuries)," The Great Circle, XVIII, No. 1 (1996), 2 and 4; AOM 1383, f. 92, Wignacourt to Pagliaro, 2 April 1605; AOM 1389, f. 118, Wignacourt to Caloro (Genoa), 24 April 1610; AOM 1392, f. 339r, Wignacourt to Caloro, 4 July 1613; Braudel, Mediterranean, I, 604; AOM 1384, f. 318r, Wignacourt to Pagliaro, 23 September 1605; AOM 1385, f. 380, Wignacourt to Pagliaro, 16 December 1606; AOM 1392, ff. 324v-325r, Wignacourt to Caloro, 22 June 1613; AOM 259, f. 124v, 20 July 1655; AOM 267, f. 167, 10 June 1722; and AOM 1513, f. 116v, Pinto to Grimaldi (Genoa), 20 May 1756.

${ }^{15}$ AOM 259, f. 131r, 31 August 1655; f. 125v, 6 August 1655; Dal Pozzo, Historia della S. Religione Militare, II, 227-228; and AOM 265, f. 204r, 1 April 1708. 
Milan to Genoa. Later that year, the Order was waiting anxiously for the deposit of more money in Genoa from its estates in Germany. These funds were to be used for the purchase of much-needed wheat. When these remittances were instead directed to Venice, the Order's agent in Milan, Quartieri, was quickly told to make amends. In 1610, after 7900 scudi had already been transferred to Genoa via Milan, the Order was again annoyed that the German funds were being directed towards the Adriatic instead of Genoa. In 1618, 4000 libre were transferred from Milan to Genoa. The following year, 1000 ducats were received in Genoa from Milan. ${ }^{16}$

Once the Order's funds from the European estates were collected, normal practice was to transfer them directly to Malta or to a Tyrrhennian market. The choice often was between Messina or Palermo, Sicilian cities with two of the busiest mints in the Mediterranean, where the remittances could be exchanged with relative ease into Sicilian scudi, a currency which continued to circulate in Malta even after the arrival of the Knights. ${ }^{17}$ More often than not, the Order had to have capital available in Sicily to buy wheat. Droughts, famines and market closures due to plagues and diplomatic incidents rendered Malta highly vulnerable to food shortages. The umbilical cord tying Malta to this nearby granary had not yet been severed: failure to import grain from Sicily could lead to famine in Malta, and failure to have the necessary capital in Italy could lead to the same perilous result.

When the occasion arose, the Order preferred to ship its remittances to Sicily, or directly to Malta, rather than use the bolle or other forms of credit transfer. To lower expenses, the Order sometimes did not insure the funds, as happened in 1665 when a cargo of silver ingots, Spanish pieces-of-eight and doppie were to be shipped from Genoa to Messina or Palermo "at the Order's

16“"Cavalieri per grazia d'Iddio e per umano ardimento. Commenda di San Giovanni di Prè," in La Devozione e il Mare (Genoa, 2000), 58; AOM 1381, ff. 122v123r, Wignacourt to Staiti (Messina), 11 May 1602; AOM 1390, f. 276, Wignacourt to Caloro, 24 August 1611; AOM 1388, ff. 267v-268r, Wignacourt to Caloro, 14 August 1609; AOM 1384, f. 40, Wignacourt to Pagliaro, 20 January 1605; AOM 1385, ff. 53v-54r, Wignacourt to Pagliaro, 23 January 1606; AOM 1386, Wignacourt to Bertone (Milan), ff. 83v-84r, 21 March 1607, ff. 102v-103r, Wignacourt to Pagliaro, 24 April 1607, Wignacourt to Pagliaro, f. 217r, 2 September 1607, f. 239r, Wignacourt to Muchental (Germany), 20 September 1607, f. 287, Wignacourt to Pagliaro, 14 November 1607, and f. 287v-288r, Wignacourt to Quartieri (Milan), 14 November 1607; AOM 1389, f. 157v, Wignacourt to Quartieri, 12 June 1610, and f. 244r, Wignacourt to Caloro, 4 August 1610 ; AOM 1397, f. 230 v, Wignacourt to Caloro, 8 July 1618 ; and AOM 1398, f. 244v, Wignacourt to Caloro, 25 June 1619.

${ }^{17}$ Braudel, Mediterranean, I, 498. A few years after its settlement in Malta the Order acquired the rights to mint its own currency, although Sicilian coins continued to circulate on the island throughout its rule. Sant, "Coinage Problems," 297-298. 
risk." Such shipments bypassed markets where losses might be incurred through the use of bills of exchange. In 1605, for example, to avoid losses due to unfavourable exchange rates, arrangements were made to ship funds to Messina with the silk galleys rather than withdraw them immediately on the market. ${ }^{18}$

As in any age, the transfer of cash was a hazardous enterprise, and more so in the Mediterranean world, where piracy and banditry were roundthe-clock professions. Genoese merchants, for example, shunned the land route from Cartagena to Barcelona, deeming the sea route safer. Philip II had to spend heavily on escorting his specie through French territory ravaged by civil war. After 1568, English privateers continually harassed Spanish silver transports along the Atlantic route to northern Europe. The Order was obviously not exempt from such worries. In 1587 a large sum from its Spanish estates was lost while being transported from Aragon to Catalonia. In 1639 Spinola, the Order's agent in Genoa, was asked to study the best way to deliver a considerable sum to Malta "safely." In 1664 advice was given to deposit funds from Aragon in Madrid rather than Valencia, since the trip to the latter was deemed dangerous for undisclosed reasons. ${ }^{19}$

Climate, seamanship and the Order's commitment to the Christian cause were other factors which affected the transport of specie. When in 1653 it needed to withdraw funds from Spain while avoiding the losses incurred by exchange, the Order considered sending its galleys to transport the money in cash. But the squadron could only be employed until the following August, which meant that the return trip from Spain would have to take place in winter. The pilots of the galleys, summoned to offer their advice, were opposed to the winter trip, claiming that weather conditions would be too hazardous and that they lacked the nautical and geographic expertise to navigate the northwestern Mediterranean. Some had not sailed in those waters during the winter months for years and believed that such a trip could not be made without "foreign" pilots. Wintering with the galleys in Spain, on the other hand, would have created provisioning and clothing problems for the crew. The Treasury's advice was to freeze the funds in the Spanish priories and postpone the trip until the spring of 1655. Such an option was not without its inconveniences for the Hospitaller hierarchy, since a spring trip would clash with a commitment to send the squadron east to relieve the Kingdom of Candia, which was besieged

${ }^{18}$ AOM 261, f. 22r, 8 May 1665; AOM 259, f. 85, 17 November 1653; AOM 1384, f. 142, Wignacourt to Pagliaro, 3 May 1605; and f. $174 \mathrm{v}-175$ r, Wignacourt to Pagliaro, 8 June 1605.

${ }^{19}$ Braudel, Mediterranean, I, 482, 484 and 490; Dal Pozzo, Historia della S. Religione Militare, I, 285; AOM 1418, f. 98, Castellar to Spinola, 24 May 1639; and AOM 261, f. 13r. 
by the Ottomans. Undecided on whether to sacrifice its own interest to its duty towards Christianity, Venice and Rome were informed eventually that only some of the fleet would sail to Candia. ${ }^{20}$

Diplomacy was also a consideration, although the present study can boast of only one relevant episode, which is too meagre to draw any kind of conclusion yet too pertinent to be ignored. Genoese-Hospitaller relations had been marred since the second half of the sixteenth century by endless squabbling over the nature of the salutes at sea and the positions that each side should occupy in the various allied Christian armadas assembled for missions in the Levant. ${ }^{21}$ The creation and observance of the rules of protocol at various diplomatic levels have always had their weight in the relations between peoples. In early modern society, however, the recognition of rank, whether in courts, military circles or at sea, was sought with a dogged assertiveness which, unless studied within the confines of Baroque ceremoniality, baffles the modern observer. ${ }^{22}$

In November 1655 the Order's fleet from Marseilles to load funds was heading to Genoa to repay debts amounting to 25,000 doubloons. Fearing further trouble with the Republic, the commander had been given strict instructions not to enter Genoa with Capitana, the flagship, but to head further south and to harbour in Portofino. The cash in gold coins was to be sent to Genoa in two galleys after the first stop at Savona, as was done in July 1613, when only two galleys were sent to collect funds from Genoa after the fleet had stopped in Savona on its return from Spain. But following advice from the receiver in Genoa that it would be more profitable to cover the debt in reali rather than gold, Capitana stopped at the quay without entering the harbour and unloaded the money. The intention was to leave for Portofino that night, but an abrupt change in the weather forced the galleys to remain in Genoa. The Hospitaller general, however, failed to salute Genoa's flagship, and the squadron was only allowed to leave after being forced to render the normal salute. On its return trip to Malta, the Hospitaller squadron had its petty revenge on a Genoese merchant ship near Civitavecchia. The whole episode sparked off the most severe diplomatic rift with Genoa since similar arguments over ritual had started a century earlier. Official correspondence was interrupted, and the Or-

${ }^{20} \mathrm{AOM} 259$, ff. $99 \mathrm{v}-100 \mathrm{r}$.

${ }^{21}$ For a chronological overview of a good number of these expeditions, see Dal Pozzo, Historia della S. Religione Militare, passim.

${ }^{22}$ Kirk, "Ceremony at Sea," not only views such incidents in context but also demonstrates the political "implications" that ensued. 
der withdrew its receiver from Genoa. ${ }^{23}$ Normal contacts were only restored near the end of the century after arbitration by the Papacy. Consequently, this half-century of Genoese-Hospitaller relations contains gaps which the research for this study cannot fill.

Genoa, of course, had much more to offer than mere geographic location and port facilities. The city's renown in the world of finance was highly valued by the Hospitallers. Its relationship with capital had been nurtured since medieval times. In pre-industrial Europe, where investment in land predominated, the Genoese, not least because of the constraints of their territory, diverted most of their energies to the sea and the management of capital. ${ }^{24}$ Their banking facilities on a continental scale were among the most flexible and sought-after of the age, and their expertise in the field of credit transfers had been proven, especially from the second half of the sixteenth century when Spain solicited their services to manage the bullion from America that financed the war in the Netherlands. They recovered swiftly from the Spanish bankruptcy of 1557; withstood the hostility of the Spanish Cortes and met the challenge of foreign merchants in every market; dominated the fairs of Piacenza; smuggled currency from Catalonia to Italy; and were the undisputed masters in dealing with paper money. Genoa's mint was among the busiest in the Mediterranean. ${ }^{25}$ Indeed. Like grain, capital seemed to materialise out of thin air in Genoa, and the Order, out of convenience, opportunity or sheer need, was more than willing to add its name to the list of clients of the maritime republic. ${ }^{26}$

The direct shipment of funds to Malta was often deemed impracticable. ${ }^{27}$ Thus, most of the time the Order had to resort to a banking facility or other form of credit transfer. Normal practice demanded the deposit of the responsions from one region or country in a local bank. The monies from the

${ }^{23}$ Dal Pozzo, Historia della S. Religione Militare, II, 228-230; AOM 1392, f. 374, Wignacourt to Caloro, 22 July 1613; and Kirk, "Ceremony at Sea," 8.

${ }^{24} \mathrm{On}$ the territory of Genoa and the district of Liguria, see S.A. Epstein, Genoa and the Genoese 958-1528 (Chapel Hill, NC, 1996), chap. 1; and J. Heers, Genova nel ' 400 (Milan, 1991), chap. 1.

${ }^{25}$ For an overview of Genoese financial activity, see Braudel, Mediterranean, II, especially 500-517.

${ }^{26} \mathrm{~F}$. Braudel, Civilization and Capitalism, 15th-18th Century. III: The Perspective of the World (London, 1985), 162.

${ }^{27}$ For example, in the spring of 1606 , the Order had to cancel plans to ship to Malta a handsome sum from Barcelona. AOM 1385, f. 155, Wignacourt to Pagliaro, 20 May 1606. 
French estates, for example, were usually deposited in Lyon and those of the Spanish estates in Madrid. ${ }^{28}$ The next stage was the transfer of these funds using a receipt, the bolla, to a market where large sums of capital were available. The choice often was Genoa. Once the remittances from western and central Europe were deposited there, the Order had more than one option to transfer them to Malta. The choice was ultimately dictated by the contingencies of the moment, which varied from the availability of currency and the rates of exchange in the main markets of the Tyrrhennian, to the urgency with which the island needed currency, to the availability of the vessels for the transport of cash.

The Order's Treasury monitored fluctuations in currency values on those markets in which its monies could be exchanged. It often complained about losses incurred by the time it received its funds from the continent. When the rates of exchange in Sicily were deemed unfavourable or prohibitive, the Genoese market was usually an alternative. In May 1605 the Treasury, deeming the rates in Palermo "unbearable," asked its agent in Genoa for information on the rates, the best timing for an exchange and the quantity of capital available. When in 1664 the receipts for Spanish funds failed to attract a good price in Palermo, soundings were carried out in Genoa in the hope of finding more attractive rates. In 1644, on the other hand, up to 40,000 scudi were to be transferred to Palermo from Genoa to exploit a favourable rate of exchange. If deemed reasonable, funds were cashed in Genoa right away and shipped to Malta. More than once, remittances from European estates were deposited there on purpose. In June 1606 information on the rates of exchange between the Genoese and Catalan markets was required when the Order wanted to transfer funds that had been deposited in Barcelona. In 1610, however, remittances from Milan to Genoa were interrupted after 1300 scudi had already been delivered when it was deemed wise to await better rates of exchange. ${ }^{29}$

When the funds deposited in Genoa were to be transferred south to another Italian city, usually the last step before being sent to Malta, various options were considered, and often it was the receiver's job to choose the most favourable. In this respect the receiver's role was not unlike that of the Venetian fattori, who were constantly searching for favourable deals for the Serenissima in the Levant. In 1605, remittances deposited in Genoa, including

${ }^{28}$ AOM 261, ff. 162v-163r, 19 April 1670; AOM 262, ff. 68-69v, 16 July 1677; and AOM 647, f. 257, 13 February 1705.

${ }^{29} \mathrm{AOM}$ 1385, f. 155, Wignacourt to Pagliaro, 20 May 1606; AOM 260, f. 179v, 4 March 1664; AOM 1422, f. 55r, Castellar to Spinola, 15 February 1644; AOM 1385, f. 192v, Wignacourt to Pagliaro, 9 June 1606; and AOM 1389, f. 402, Wignacourt to Caloro, 19 December 1610. 
those from Milan, were to be transferred either to Naples, Palermo or Messina. In 1607, Florence was chosen as an alternative to Genoa for the remittance of funds from Germany. At times Genoa was by-passed altogether. In 1677, some French and Spanish funds were deposited in Leghorn using Mexican pieces-of-eight and the currency of Seville. The remaining sums were to be divided and deposited partly in Palermo and the rest directly in Malta. ${ }^{30}$

The choice to deposit funds in markets other than Malta or Sicily was dictated by the needs of the Order and its post. In 1618, remittances from Genoa, Lombardy or Venice were expected in Naples for 1000 cantara of biscuits, while in 1622 bills of exchange for 1000 scudi were delivered to Naples from Genoa to buy biscuits and to cover the cost of building a new galley. ${ }^{31}$

Although maintaining a regular flow of remittances from the continent received constant attention, it still did not spare the Order from shortages and the need for supplementary funds. A temporary solution was sometimes sought through special impositions on the European estates, as in 1558, 1574, 1583, 1631,1633 and 1645 . Such extraordinary measures, which were usually successful, provided relief for the Treasury and enabled the Order to continue drawing on its own resources. ${ }^{32}$ The obvious limitation of such taxes was that their collection was subject to the vicissitudes of the estates: in 1638, estates in Calabria were damaged by an earthquake; in 1640, those in Casale were ravaged by Spanish troops; in 1650, an agent lamented the consequences of war on property in Inverno (five years later, the same agent was still complaining about this); and in 1703, the estates in Lombardy were flooded. A year later, the Order's Council was briefed about the difficulty of withdrawing the usual funds from France, Spain and Portugal due to war. The widespread disruption caused by the Thirty Years' War was disastrous for more than one Hospitaller priory. Writing on the "stato penurioso della Religione," the contemporary historian Dal Pozzo, perhaps not without some exaggeration, described how for twenty years no German remittances were received; how damages to Italian

${ }^{30}$ Braudel, Mediterranean, II, 465; AOM 1383, Wignacourt to Pagliaro, f. 334r, 27 September 1604; AOM 1384, f. 95v, Wignacourt to Pagliaro, 2 April 1605; AOM 1386, f. 239r, Wignacourt to Muchental (Germany), 20 September 1607; and AOM 262, ff. 68-69v, 16 July 1677.

${ }^{31}$ AOM 1397, f. 17r, Wignacourt to Balsamo (Naples), 13 January 1618; and AOM 1401, f. 190, Wignacourt to Torriglia (Genoa), 9 April 1622.

${ }^{32}$ Hoppen, "Finances," 108-109. Those in 1574 and 1583 were made permanent and were added to the responsions exacted annually. 
estates had reduced the flow of funds from the peinsula; and how transfers from Spain had been cut by half. ${ }^{33}$

Verification of the impact of such calamities on the Order's coffers presents difficulties for reasons already discussed. It is clear, however, that great losses were incurred. Because of such contingencies, the Order could not renounce extraordinary sources of fresh capital. Indeed, the Order was enterprising enough to follow the contemporary trend in the larger European states by making an overseas investment when it purchased the Caribbean islands of St. Christopher. ${ }^{34}$ Although innovative, such investments yielded profits only in the long term. When capital was needed more urgently, the Order, like other states in Europe, had to resort to loans. In the second half of the sixteenth century, seventy-five percent of the expenditures of Spain and England were consumed by war and debt repayments related to past conflicts. By 1651 , the debt of the province of Holland amounted to 153 million florins. Although engaged in a conflict different in scale and nature to the ones which were being waged on the continent, Hospitaller Malta was still at war, and this required money. In 1581, prompted by several warnings of an attack by the Ottomans, orders were given to raise a loan of 40,000 scudi. Although the rumours gradually subsided, they had been alarming enough to warrant the garrisoning of the sister island of Gozo. In 1574, envoys were sent to Spain to raise a loan of up to 100,000 scudi. ${ }^{35}$ According to Dal Pozzo, by 1640 the Order had contracted loans of 192,000 scudi for fortifications. ${ }^{36}$ Five years later, an even heftier loan of 400,000 scudi was contracted. States devised all sorts of financial mechanisms to obtain the currency needed to sustain their war efforts. The Dutch reverted to public loans to sustain hostilities with the Habsburgs in the mid-seventeenth century. In Tudor England, confiscated church property was

${ }^{33}$ Dal Pozzo, Historia della S. Religione Militare, II, 53 and 273; AOM 1419, f. 82v, Castellar to Spinola, 16 June 1640; AOM 1428, f. 173v, Castellar to Spinola, 31 October 1650; AOM 1432, f. 149, Castellar to Spinola, 11 September 1655; AOM 647, f. 224r, 24 July 1703, and AOM 647, f. 253r, 24 October 1704.

${ }^{34}$ For the purchase of the island, see L. de Boisgelin, Ancient and Modern Malta (2 vols., London, 1805), I, 77-79; for their profitable sale, see Dal Pozzo, Historia della $S$. Religione Militare, II, 673-674.

${ }^{35}$ Kennedy, Rise and Fall, 87, 89 and 91; and Dal Pozzo, Historia della S. Religione Militare, I, 101 and 174-175.

${ }^{36}$ The repayment was effected through the passaggi paid by 120 newly admitted Hospitallers. Dal Pozzo, Historia della S. Religione Militare, II, 52. 
sold, loans were raised and taxes increased to reduce the war deficit. ${ }^{37}$ The services of professional financiers, banker and wealthy merchants were sought. The Order also acted as a creditor, even on an international level, and had done so since medieval times. ${ }^{38}$ In 1603 , for example, the Emperor of Hungary asked for financial aid to maintain the defences against the Turks; the Order attributed its refusal to comply to the burden of its own debts. ${ }^{39}$

Genoa's capacity to obtain the liquidity demanded by the Order, either in the form of loans or by clearing bills of exchange, was repeatedly recorded in Hospitaller documents. In 1645, for example, the Order turned to its agent in Genoa, Spinola, to cover debts in Naples on which large sums of interest were being paid. The following year, Spinola was described as the sole agent capable of covering the payment of 60,000 scudi withdrawn from Palermo. The next year, the same agent was on the verge of concluding a deal to transfer 100,000 scudi to Palermo to purchase wheat. By October, he had already managed to deliver a quarter of this sum, which was quite a feat considering the difficulties the Order was encountering in finding the necessary capital. In 1766 the captains of two Catalan pinks were provided with two bills of exchange in Malta to be cashed in Genoa after their wheat cargoes from Girgenti (Sicily) were confiscated to replenish the island's granaries. There were exceptions, of course. Despite its financial allure, Genoa, like all markets, was subject to economic forces beyond its control and at times failed to deliver the goods, as in 1566, when money was "tight." In 1648, the Order's agent in Genoa encountered too many difficulties to raise $18,000 \mathrm{scudi}$, and by the following February the scarsezza on the Genoese market was still hindering him from sending currency to Messina, where provisions were being sought despite the bad harvests. Wary of the consequences if the required sum was not delivered, the agent sent news that France was being less strict with the release of the tratte, the licences for the duty-free export of wheat. When the scarcity of coins affected more than one market, the Order found great difficulty in clearing the bolle for its remittances from Europe. In 1708 it asked the Università, the body which administered the distribution of wheat on the island, for a loan

${ }^{37}$ Ibid., I, 102; Kennedy, Rise and Fall, 89; and G. Parker, The Military Revolution (Cambridge, 1988), 62-64.

${ }^{38}$ For some examples of the Order's financial dealings during the Middle Ages, see A. Luttrell, "Interessi fiorentini nell'economia e nella politica dei Cavalieri Ospedalieri di Rodi nel Trecento," in T. Bolelli (ed.), Annali della Scuola Normale Superiore di Pisai (Pisa, 1959), 317-326; and Luttrell, "Actividades economicas de los Hospitalarios de Rodas en el Mediterraneo occidental durante el siglo XIV," in VI Congreso de Historia de la Corona de Aragon (Madrid, 1959), 175-183.

${ }^{39}$ Dal Pozzo, Historia della S. Religione Militare, I, 489-490. 
of 100,000 scudi, with the interest to be covered by the Hospitallers and lay members of the population who were indebted to the Order. ${ }^{40}$

Genoa was at times examined simultaneously with other markets. As with rates of exchange, before contracting a loan the Order considered several markets to seek the lowest possible interest rates. In June 1722 Rome was preferred to Genoa for a loan of 80,000 genovine since the three percent interest rate offered by the former was half a percent lower than that offered in Genoa. Three months later, alarmed by disturbing dispatches from Constantinople regarding an imminent attack, the Treasury was asked to raise yet another loan "in Genoa or somewhere else." When the need for capital was pressing, dispatches were sent to various markets to increase the possibilities of a favourable reply. In 1622, a loan of up to 60,000 scudi was sought in Genoa, Rome and elsewhere. In 1646, in the midst of a difficult decade for Hospitaller Malta, Palermo, Naples, Florence and Messina, as well as Genoa, were tested, while the Treasury in Malta, as was customary in times of financial difficulty, started to mint large quantities of copper currency. Apart from rich Genoese merchants, the government of the Republic could also be approached. In the early 1760s, another decade of poor harvests in Sicily with ensuing shortages for Malta, the Order officially asked the Republic for a loan. The appeal seems to have received a cold reception in Genoa despite the persistent demands by Grand Master Pinto. ${ }^{41}$

The granting of a loan usually required following certain basic rules. Much depended upon the creditworthiness of the debtor; the sounder his reliability and the greater his "repayment potential," the more likely that a loan would be forthcoming, sometimes at reduced rates. Seventeenth-century Holland, for instance, was granted loans of millions of florins because it was backed by considerable economic strength. The Genoese granted loans to Habsburg Spain against the assurance of the arrival in Seville of silver from the Indies. In the second half of the sixteenth century, English borrowing on

${ }^{40} \mathrm{AOM} 1423$, ff. $114 \mathrm{v}-115 \mathrm{r}$, Castellar to Spinola, 8 April 1645 , and f. 258 , Castellar to Spinola, 19 October 1645; AOM 1424, f. 97, Castellar to Spinola, 31 May 1646: AOM 1425, f. 130v, Castellar to Spinola, 12 October 1647; AOM 1522, ff. 194v-195r, Pinto to Grimaldi (Genoa), 29 September 1766; Braudel, Mediterranean, II, 489; AOM 1426, ff. 205v-206r, Castellar to Spinola, 11 December 1648; AOM 1427, ff. 34v-35r, Castellar to Spinola, 6 February 1649; and AOM 265, ff. 215v-216r, 20 August 1708.

${ }^{41}$ AOM 267, f. 129r, 10 June 1722, and f. 147r, 25 September 1722; AOM 1401 , f. 422, Wignacourt to Ambassador Falco (Rome), Torriglia (Genoa), and Scalamanti (Venice), 9 August 1622; AOM 1424, f. 134v, Castellar to receivers of Palermo, Naples, Florence, Messina and Genoa, 10 August 1646; AOM 1517, ff. 48v49r, Pinto to Gimaldi (Genoa), 27 February 1761, f. 88r, 21 May 1761, and f. 132r, 27 July 1761; and Sant, "Coinage Problems," passim. 
the Antwerp bourse was interrupted when English privateers started disrupting the transport of Spanish silver. Meanwhile, the only collateral the Order could offer was its property. The Hospitaller hierarchy strove hard to sustain an aura of credibility. The punctual payment of interest and principal often demanded creativity and rapid action on the international markets. In 1650, debts contracted in Genoa at eight percent interest were cleared by another loan of 30,000 scudi contracted in Rome by pledging Hospitaller property in the Papal States. In 1715, annual interest of 9000 Roman scudi was covered by taxes due the Treasury on all the property in the Papal States and the Kingdom of Naples. In 1734 the Treasury proposed substituting Genoese with Maltese creditors to clear debts of 80,000 genovine in the Republic. This proposal was motivated by the eventual reduction in interest payments and the alternative investment opportunity being offered to the pubblico, the creditors on the island. Decisions on similar matters were at times the source of conflict between the Treasury and the Council. In 1655, the Procurators suggested that a debt of 49,000 mezze doppie owed to Genoa should not be paid immediately if annual remittances from the Spanish and French estates were not withdrawn. The Procurators argued that some other expenses warranted absolute priority. The Council overruled this proposal, justifying its decision by the need to safeguard its reputation as much as the need to save on annual interest payments. ${ }^{42}$

The Order's efforts to maintain a high credit rating were at times put to the test. In 1639 , negotiations to borrow money in Genoa were interrupted due to the excessive guarantees being demanded on that market. In August 1722 , the Order's creditors in Rome demanded additional guarantees for a loan of 80,000 genovine. ${ }^{43}$ These, however, seem to have been exceptional episodes.

The financial relationship between Malta and Genoa remained alive throughout the 1700s. Despite being replaced in 1627 by the Portuguese marranos as the leading creditors to Habsburg Spain, the Republic managed to retain much of its traditional vitality as a financial centre, amply capable of satisfying the needs of a small state like Hospitaller Malta. When in 1743 the Order wished to reorganize its ledgers, Genoa was asked to provide two financial experts to carry out the task. A document on the alteration of exchange

${ }^{42}$ Kennedy, Rise and Fall, 89; Braudel, Mediterranean, I, 482; AOM 258, f. 211v, 16 March 1650; AOM 266, ff. 153v-154r, 26 March 1715; AOM 269, f. 32, 29 October 1734; AOM 259, f. 131r, 31 August 1655, and f. 126v, 13 August 1655; and Dal Pozzo, Historia della S. Religione Militare, II, 227.

${ }^{43}$ AOM 1418, ff. $141 \mathrm{v}-142$ r, Castellar to Spinola, 7 August 1639; and AOM 267, f. 140v, 16 August 1722. 
rates between Genoa and Madrid shows that the Order was still channelling all its Spanish funds through Genoa up to the mid-1790s. ${ }^{44}$

By that time the Order was facing a sprawling financial crisis caused by the loss of its French estates. Debts were being paid in Rome, Valladolid, Turin, Madrid and Genoa. Loans from the Republic, in fact, were negotiated up to the 1790s. In January 1792, Genoa granted a loan of 800,000 livres to the Order against a pledge of all Hospitaller property in Liguria, the Genoese district. It was to be one of the last negotiations of its kind between the two parties. The decade was to end traumatically for both the Republic and the Order. Both were sucked into the whirlpool of the French Revolution. The anti-religious and highly nationalistic sentiment that swept Revolutionary France disrupted the life of the Hospitallers irrevocably. The confiscation of the Order's French estates in 1792 deprived Malta of about one-sixth of its annual income. Other estates were confiscated in Poland in 1793. By 1795 the Order had lost seventy-five percent of its annual continental income. As these financial blows escalated, it became evident that the Order was in no position to repay its debts. In 1794 a six-year extension was obtained on the loan contracted two years earlier. The repayment, which was already overdue in 1793 , was finally made in 1798. This postponement provided only insignificant relief, though; more funds were needed, and the Order again knocked on Genoa's doors. In the beginning of 1797, the receiver in Genoa, Francesco Lomellino, was asked to find a consortium of creditors to lend money to the Order. Lomellino failed. The Order, understandably, had exhausted its credit with the financial circles of the Republic. This proved to be the death knell for a relationship between two small worlds overwhelmed by a Europe in turmoil. In June 1797, the old Republic of Genoa was declared defunct and replaced by the Democratic Republic of Liguria under the patronage of the occupying French forces. In June 1798 the French ousted the Order of St. John from Malta. The following month, Hospitaller property in Liguria was confiscated by the new government, and with it was lost one of the last financial connections between Hospitaller Malta and the Republic of Genoa. ${ }^{45}$

\footnotetext{
${ }^{44}$ Braudel, Mediterranean, I, 500-501; AOM 1502, ff. 35v-36r, Pinto to Grimaldi, 11 February 1743; and AOM 643, f. 223, 29 September 1794.

${ }^{45} \mathrm{AOM} 274$, f. 266v; A. Blondy, "Malta and France 1789-1798: The Art of Communicating a Cisis," in V. Mallia-Milanes (ed.), Hospitaller Malta 1530-1798: Studies on Early Modern Malta and the Order of St. John of Jerusalem (Malta, 1993), 666; Blondy, L'ordre de Malte au XVIII' siècle. Des dernières splendeurs à la ruine (Paris, 2002); I. Grech, "La confisca dei beni liguri dell'Ordine di Malta da parte della Repubblica Ligure," in J. Costa Restagno (ed.), Cavalieri di San Giovanni e Territorio. La Liguria tra Provenza e Lombardia nei secoli XIII-XVII (Genova, 1999), 207-210 and 212; AOM 267, f. 235, 1 February 1794; G. Assereto, La Repubblica Ligure. Lotte politiche e problemi finanziari (1797-1799) (Turin, 1975); P. Nurra, Problemi del Ri-
} 
The flow of capital between Genoa and Hospitaller Malta was nurtured throughout the early modern period. These ties proved strong enough to withstand the challenge by other Italian markets and to overcome the disruptions caused by rather long diplomatic interruptions. When relations were restored to normality following the mid-seventeenth-century crisis, the flow of capital towards Malta was gradually resumed. The Republic's geographic location and potential as a provider of credit were too convenient for the Order to forfeit, and financial connections were maintained up to the dying moments of both parties. As a result, the Genoa-Malta route proved to be one of the most vibrant financial links along the Tyrrhenian throughout the seventeenth and eighteenth centuries. 